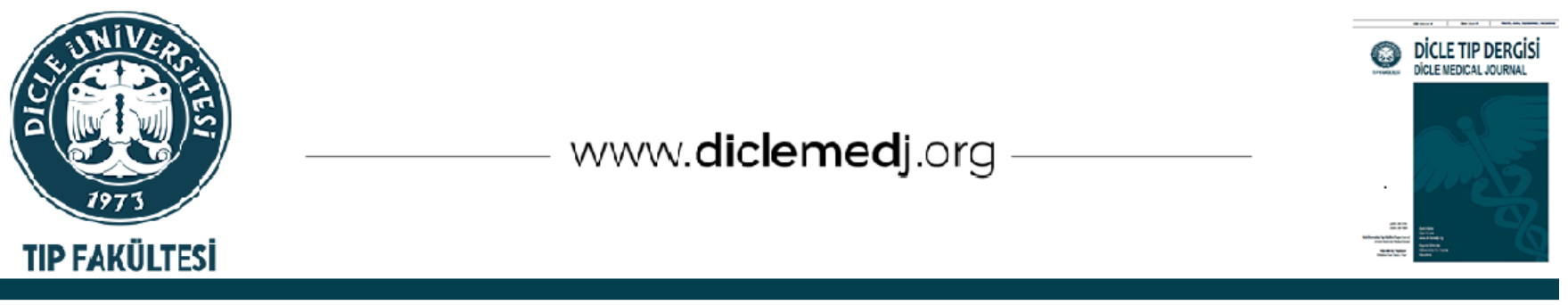

\title{
Deneysel Travmatik Omurilik Hasarında Thymbra Spicata L. Var Spicata ve Cyclotrichium Origanifolium' un Böbrek Üzerine Koruyucu Etkisinin Araştırılması
}

\author{
Figen Koç Direk ${ }^{i}{ }_{1}$, M. Cudi Tuncer ${ }^{1}{ }_{1}$, Engin Deveci ${ }^{i D_{2}}$, Beran Yokuş ${ }^{D_{3}}$, Cemal Nas ${ }^{\left(D_{4}\right.}$, Dilek Aygün Keşim ${ }^{\left(D_{5}\right.}$ \\ 1 Dicle Üniversitesi Tıp Fakültesi Anatomi Anabilim Dalı, Diyarbakır, Türkiye \\ 2 Dicle Üniversitesi Tıp Fakültesi Histoloji Anabilim Dalı, Diyarbakır, Türkiye \\ 3 Dicle Üniversitesi DÜSAM Müdürlüğü, Diyarbakır, Türkiye \\ 4 Gazi Yaşargil Eğitim Araştırma Hastanesi, Diyarbakır, Türkiye \\ 5 Dicle Üniversitesi Tıp Fakültesi Fizik Tedavi ve Rehabilitasyon Anabilim Dalı, Diyarbakır, Türkiye \\ Geliş: 30.03.2021; Revizyon: 17.05.2021; Kabul Tarihi: 18.05.2021
}

$\ddot{0} \mathbf{z}$

Amaç: Bu çalışmada Thymbra spicata L. var. spicata (zahter) ve Cyclotrichium origanifolium' un (dağ nanesi) spinal kord travmasından sonra oluşan böbrek hasarı üzerine potansiyel tedavi edici ve koruyucu etkisi araştırılması amaçlanmıştır.

Yöntemler: Ağırlıkları 250-300 gr arasında değişen 36 adet Wistar Albino erkek sıçan kullanıldı. Her bir grupta 6 adet olacak şekilde 6 gruba ayrıldı. 1.Grup; kontrol, 2.Grup; zahter, 3.Grup; dağ nanesi, 4.Grup; travma, 5.Grup; travma +zahter, 6.Grup; travma+dağ nanesi olacak şekilde oluşturuldu. Travma gruplarına spinal kord üzerine ağırlık düşürme metodu (Allen) uygulanarak travma oluşturuldu. Bir haftanın sonunda bütün sıçanlar Ketamin anestezisi altında kardiyak ponksiyonla kan örnekleri alındıktan sonra feda edilerek böbrek dokusu alındı. Dokuda histopatolojik değișiklikler incelendi. Serumda MDA, kreatinin, BUN (üre), Sodyum (Na) ve Potasyum (K) değerleri ölçüldü.

Bulgular: Böbrek dokusunda histopatolojik inceleme sonucu, travma grubunda glomerüler yapıların atrofiye uğradığı, tübüllerde dejenerasyon olup yapısının bozulduğu, damarlarda konjesyon olduğu ve mononükleer hücre infiltrasyonunun arttığı görüldü. Travma + zahter ile travma + dağ nanesi gruplarında ise travma grubuna göre glomerüler yaplarda düzelme olduğu, yer yer mononükleer hücre infiltrasyonunun düzeldiği görüldü. Serum MDA, BUN (üre), Na ve K değerlerinin travma grubunda diğer gruplara göre artığı $(\mathrm{p}<0.05)$, travma+zahter ve travma+dağ nanesi gruplarında istatistiksel olarak anlamlı olmasa da azaldığı görüldü ( $\mathrm{p}>$ 0.05). Serum kreatinin düzeyinin ise travma+zahter grubunda kontrol grubuna göre anlamlı düzeyde azaldığı görüldü (p< 0.05).

Sonuç: Thymbra spicata L. var. spicata (zahter) ve Cyclotrichium origanifolium' un (dağ nanesi) omurilik yaralanmasına bağlı böbrek hasarına karşı kısmen etkili olduğu zahterin dağ nanesine göre etkinliğinin daha fazla olduğu belirlenmiştir.

Anahtar kelimeler: Spinal kord hasarı, Böbrek, Antioksidan, Zahter, Dağ nanesi

DOI: 10.5798/dicletip.944388

Yazışma Adresi / Correspondence: Figen Koç Direk, Dicle Üniversitesi Tıp Fakültesi Anatomi Anabilim Dalı, Diyarbakır, Türkiye e-mail: figen11kd@gmail.com 


\title{
Investigation of the Protective Effect of Thymbra Spicata L. Var Spicata and Cyclotrichium Origanifolium on Kidney in Experimental Traumatic Spinal Cord Injury
}

\begin{abstract}
Objective: In this study, it was aimed to investigate the potential therapeutic and protective effects of Thymbra spicata L. var. spicata (zahter) and Cyclotrichium origanifolium (mountain mint) on kidney damage after spinal cord trauma.

Method: 36 Wistar Albino male rats, weighing between 250-300 g, were divided into 6 groups with 6 in each. Group 1; control, Group 2; zahter, Group 3; mountain mint, Goup 4; trauma, Group 5; trauma + zahter Group 6; trauma + mountain mint. Trauma was created by applying weight reduction method (Allen) on the spinal cord in trauma groups. At the end of one week, all rats were sacrificed after blood samples were taken by cardiac puncture under ketamine anesthesia, and kidney tissue was taken. Histopathological changes in the tissue were examined. MDA, creatinine, BUN (urea), Sodium ( $\mathrm{Na}$ ) and Potassium (K) values were measured in serum.

Results: As a result of histopathological examination of the kidney tissue, it was observed that glomerular structures were atrophied, the structure of the tubules degenerated, the vessels congestioned and increased mononuclear cell infiltration in the trauma group. In microscopic examination, it was observed that in the trauma + zahter and trauma + mountain mint groups, there was an improvement in the glomerular structures compared to the trauma group, and some mononuclear cell infiltration was improved. Serum MDA, BUN (urea), Na and $\mathrm{K}$ values were found to be increased in the trauma group compared to the other groups ( $\mathrm{p}<0.05$ ). In addition, a decrease was observed in the trauma + zahter and trauma + mint groups, although it was not statistically significant (p> 0.05). Serum creatinine level was found to be decreased in the trauma + zahter group compared to the control group ( $\mathrm{p}<0.05$ ).
\end{abstract}

Conclusıon: It was determined that Thymbra spicata L. var. spicata (zahter) and Cyclotrichium origanifolium (mountain mint) were partially effective against kidney damage due to spinal cord injury and zahter was more effective than mountain mint.

Keyword: Spinal cord injury, Kidney, Antioxidant, Zahter, Mountain mint.

\section{GíRiş}

Spinal kord travması sonrası hastalarda ciddi nörolojik hasar ve çoklu organ fonksiyon bozuklukları meydana gelmektedir ${ }^{1}$.

Travmada birincil etki omurilikte olmakla birlikte nörojenik hasar sonrasında biyokimyasal, moleküler ve hücresel değişikliklere bağlı olarak ikincil hasar oluşmakta akciğer, karaciğer böbrek gibi organların zarar görmesine neden olmaktadır².

Böbrek yetmezliği, omurilik yaralanmasından sonra ortaya çlkabilecek çoklu organ yetmezliğinin ciddi bir bileșenidir ${ }^{3}$. Modern terapötik seçeneklerin geliştirilmesiyle hayati tehlike oluşturan etkileri son zamanlarda azalmış olsa da, spinal kord yaralanmasına bağlı renal komplikasyonlar önemli bir problem olmaya devam etmektedir ${ }^{4}$.

Yapılan çalışmalar omurilik yaralanmalarının böbrek dokusunda belirgin yapısal, fizyolojik ve moleküler değişikliklere neden olduğunu göstermiştir ${ }^{5}$. Spinal kord yaralanmasından 24 saat sonra böbrek dokusunda, serbest radikal konsantrasyonunda ve lipid peroksidasyon düzeyinde büyük bir artış görülür ${ }^{3}$. Bu artış oksidatif stres ve inflamatuvar yolakların aktivasyonuna bağlı olarak doku hasarını artırır.

Serbest radikal konsantrasyonunu, lipid peroksidasyon derecesini ve oksidatif hasarı düşürmek için tedavide etkili ajanların kullanılması bir sonuç elde etmemize yardımcı olabilir.

Omurilik yaralanmalarına bağlı doku hasarlarında rol oynayan faktörler göz önüne alındığında antioksidan ve antiinflamatuvar ajanların spinal kord hasarı sonucu gelişen böbrek disfonksiyonun da klinik yararlarının olduğu gösterilmiștir6.

Cyclotrichium origanifolium (dağ nanesi); geleneksel olarak yatıştırıcı, gevşetici, gaz giderici ve solunum yolu rahatsızlıklarının tedavisi için kullanılmaktadır. Cyclotrichium origanifolium' un güçlü bir serbest radikal temizleme aktivitesine sahip olduğu dolayısıyla 
antioksidan ve antimikrobiyal etkisinin fazla olduğu yapılan çalışmalarda belirtilmiştir ${ }^{7,8}$.

Thymbra spicata L. var. spicata; kekik veya zahter olarak bilinir. Carvakrol ve Thymol gibi çok güçlü bileşenler içermektedir. Gıda endüstrisinde lezzet ve aroma için kullanılmasının yanı sıra birçok hastalığın tedavisinde de kullanılmaktadır. Yapılan çalışmalarda antioksidan, antiinflamatuvar, antimikrobiyal, analjezik ve nöroprotektif etkisi gösterilmiştir9-11. Thymbra spicata L. var. spicata, birçok ülkede ilaç endüstrisinde ham madde olarak kullanılmakta ve bileşenleriyle geleceğin ilacı olarak önem taşımaktadır ${ }^{12}$.

Geniş biyolojik aktiviteye sahip olan zahter ve dağ nanesinin, antiinflamatuvar, antioksidan antibakteriyel ve nöroprotektif etkisi birçok araștırmada gösterilmesine rağmen travmatik omurilik yaralanması sonucu oluşan böbrek hasarı üzerine etki mekanizmalarını gösteren çalışma bulunmamaktadır. $\mathrm{Bu}$ durum çalışmamızın özgünlüğü açısından ayrı bir önem taşımaktadır.

$\mathrm{Bu}$ çalışmayla omurilik yaralanması sonrası gelişen böbrek hasarı üzerine zahter ve dağ nanesinin oksidatif stres, renal fonksiyon ve histopatolojik değişikliklere olan etkisinin araştırılması amaçlanmıştır.

\section{YÖNTEMLER}

\section{Deney Hayvanları}

Bu çalıșma, Dicle Üniversitesi Hayvan Deneyleri Etik Kurulu (DÜHADEK) tarafından 30/05/2019 tarih, 2019/08 protokol numarası ile onaylanmıştır. Çalışmadaki deney hayvanları Dicle üniversitesi deney hayvanları laboratuvarından temin edilmiştir.

Ağırlıkları 250-300 gr arasında değișen 8-10 haftalık Wistar Albino erkek sıçanlar kullanıldı. Siçanlar paslanmaz çelik kafeslerde $22 \pm 2{ }^{\circ} \mathrm{C}$ de 12 saat aydınlık ve 12 saat karanlıkta normal diyet ve musluk suyu ile herhangi bir kisitlama yapılmaksızın beslenildi. Omurilik travması oluşturmak üzere cerrahi girişim yapılan sıçanlara ketamin ve Xylazin intraperitoneal olarak verildi. Sıçanlar mantar bloklar üzerinde prone pozisyonunda yerleştirildi. PVD iyodin ile sterilizasyon sağlandı. T5-T12 arası orta hattan insizyon yapılarak açıldı. Paravertebral kaslar sıyrılarak laminalar açıı̆a çıkartıldıktan sonra T6-T7-T8 laminektomi yapıldı. Omurilik hasarı oluşturmak için ağırlık düşürme modeli (Allen 1911) uyguland ${ }^{13}$. Bu model doğrultusunda, $3 \mathrm{~mm}$ çapında ve 10 gr ağırlı̆̆ında bir çelik çubuk $10 \mathrm{~cm}$ ' den düşürülerek omurilik yaralanması oluşturuldu. Travma oluşturulduktan 30 dakika sonra ve bir hafta boyunca günde bir kez $4000 \mathrm{ppm} / \mathrm{kg}$ dozda intraperitoneal yolla gruplara göre zahter ve dağ nanesi ekstraktları verildi. Kontrol grubuna ise aynı dozda intraperitoneal yolla serum fizyolojik verildi. 36 adet Wistar Albino sıçan her bir grupta 6 adet olacak şekilde 6 gruba ayrildl.

1.Grup: Kontrol: Sağlıklı deney grubunu oluşturan bu gruptaki sıçanlara travma oluşturulmadı. Plasebo olarak, bir hafta süresince intraperitoneal yolla $4000 \mathrm{ppm}$ $/ \mathrm{kg} /$ gün dozda serum fizyolojik uygulandı.

2.Grup: Zahter: Sağlıklı deney grubunu oluşturan bu gruptaki sıçanlara travma oluşturulmadı. 4000ppm /kg/gün \%1lik etanol çözeltisinde çözünmüş halde zahter bir hafta süresince intraperitoneal yolla uygulandı.

3.Grup: Dağ nanesi: Sağlıklı deney grubunu oluşturan bu gruptaki sıçanlara travma oluşturulmadı. 4000ppm /kg/gün \%1lik etanol çözeltisinde çözünmüş halde dağ nanesi bir hafta süresince intraperitoneal yolla uygulandı.

4.Grup: Travma: Bu gruptaki sıçanlara travma oluşturuldu. Plasebo olarak, bir hafta süresince intraperitoneal yolla $4000 \mathrm{ppm} / \mathrm{kg} /$ gün dozda serum fizyolojik uygulandı.

5.Grup: Travma+zahter: Bu gruptaki sıçanlara travma oluşturuldu. $4000 \mathrm{ppm} / \mathrm{kg} / \mathrm{gün} \% 1 \mathrm{lik}$ etanol çözeltisinde çözünmüş halde zahter bir hafta süresince intraperitoneal yolla uygulandı. 
6.Grup: Travma+dağ nanesi: $\mathrm{Bu}$ gruptaki siçanlara travma oluşturuldu. 4000ppm /kg/gün \%1lik etanol çözeltisinde çözünmüş halde dağ nanesi bir hafta süresince intraperitoneal yolla uygulandı.

Travma oluşturulduktan bir gün sonra sıçanların motor fonksiyonları Drummond ve Moore kriterleri ile değerlendirildi ${ }^{14}$. Buna göre Omurilik travması oluşturulan 18 sıçanın paraplejik olduğu görüldü.

8. günde tüm gruplardaki sıçanlar ketamin anestezisi altında kardiyak ponksiyonla kan örnekleri alındıktan sonra feda edilerek histopatolojik inceleme için böbrek dokuları alındı.

\section{Bitki Örnekleri ve Uçucu Yağlarının Elde Edilmesi}

Thymbra spicata L. var. spicata (zahter) ve Cyclotrichium origanifolium (dağ nanesi) türleri doğadan toplanarak gölgede kurutulmuştur. Gölgede kurutulan bitkilerin toprak üstü kısımları küçük parçacıklar haline getirilmiş ve distilasyon aygıtı (Clevenger aparatı) içinde sıcak su ile kaynatılmıştır. Oluşan buhar ile sürüklenen uçucu yağ soğutucuda yoğunlaştırılarak bir kapta toplanmıştır. Elde edilen uçucu yağlar $+4{ }^{\circ} \mathrm{C}$ 'de $\mathrm{Na} 2 \mathrm{SO} 4$ içerisinde bekletilerek içerdiği sudan kurtarılmıştır ${ }^{15}$. Uygulama için etanol çözücüsü ile $4000 \mathrm{ppm}(\mu \mathrm{g} / \mathrm{ml})$ konsantrasyonda stok çözeltiler hazırlanmıştır.

\section{Doku Takibi}

Böbrek dokuları rutin parafin doku takibine alındı. Fiksasyon (24 saat) işleminden sonra dokular yıkama (1 gece), artan alkol serileri (\%50, \%70, \%80, \%90, \%96 ve absolü etil alkol serilerinden geçirildi) ve şeffaflaştırma (ksilende 3x30 dakika) işlemlerinin ardından $58^{\circ} \mathrm{C}^{\prime}$ de parafin infiltrasyonuna alındı. Daha sonra dokular parafin bloklara gömüldü ve mikrotom (katalog no: Leica RM2265, Wetzlar, Germany) yardımıla bloklardan
Hematoksilen-Eozin boyamalar için 4-6 $\mu \mathrm{m}$ kalınlığında kesitler alındı.

\section{Hematoksilen-Eozin Boyama}

Parafin bloklardan alınan böbrek doku kesitleri $37^{\circ} \mathrm{C}$ 'ye ayarlanmış benmariye alındı. Lam üzerinde fazla parafini eritmek için kesitler 58$62^{\circ} \mathrm{C}$ etüvde 6 saat boyunca bekletildi. Kesitler 3x15 dakika ksilende deparafinize edildi. Kesitler azalan alkol serilerinden (\%100, \%96, $\% 90, \% 70, \% 50$ etil alkol) 10'ar dakika geçirildi ve distile suya getirilerek 5 dakika bekletildi. Harris Hematoksilen boyasında 8 dakika bekletildikten sonra kesitler akan su altında 5 dakika yıkandı. Kesitler durulandı ve alkolik eozin boyasında 6 dakika bekletildi. Kesitler artan alkol serilerine (\%80, \%90, \%96 etil alkol serilerinden geçirilerek) hızlıca daldırıldı ve absolü alkolde 2 dakika bekletildi. Son olarak kesitler 3x15 dakika ksilende bekletildi ve doku üzerine Entellan damlatılarak lamelle kapatıldı. Kesitler A2 imager Zeiss ışık mikroskobu altında incelendi.

\section{Biyokimyasal Analiz}

Alınan kan örnekleri 3500 rpm' de 20 dakika boyunca santrifüj edilerek serumları alındı. Serum örnekleri biyokimyasal analiz yapılana kadar $\quad-80 \quad{ }^{\circ} \mathrm{C}$ ' de saklandl. Serumda Malondialdehit (MDA), BUN (üre), kreatinin, Sodyum (Na) ve Potasyum (K) değerleri ölçüldü. Klinik Kimya testleri, Abbot Firmasının Architech marka C1600 model Otoanalizörü cihazında çalışıldı. Serumda kreatinin ve BUN (üre) testleri fotometrik, Potasyum (K) ile Sodyum (Na) testleri Potansiyometrik Metodla çalışıldı. Serum MDA düzeylerinin ölçümü Ohkawa yöntemiyle belirlendi ${ }^{16}$. Tiyobarbitürik asitle (TBA) reaksiyona giren MDA' nin reaksiyon sonucu meydana gelen pembe renkli maddenin 532 nm' de, n-butanol'e karşı absorbansının spektrofotometrik olarak ölçümü ile lipid peroksidasyonunun (LPO) derecesi belirlendi. Serum örneklerinde MDA düzeyleri $\mu \mathrm{mol} / \mathrm{L}$ olarak verildi. 


\section{İstatistiksel Analiz}

Deney gruplarının tümü değerlendirilirken, istatistiksel analizler için $R$ stüdyo IDE proğramının R 3.6.3 versiyonu kullanılmıştır. Çalışma verileri değerlendirilirken verinin tümünde parametrik test varsayımlarını gerçekleștiremediğimizden dolayı, ikiden fazla gruplar arası farkları test etmek için parametrik olmayan istatistiksel testlerden Kruskal-Wallis tercih edilmiştir. Veri hacminin azlığından ve veri yapısının parametrik olmayan testlere uygunluğundan Tip-I hata riskini azaltmak ve testin gücünü arttırmak açısından Bonferroni düzeltmesi ile post-hoc testlerden Dunn kullanılmıştır. Ayrıca çalışma öncesi Mahalanobis uzaklığı kullanılarak veri setindeki uç değerler irdelenmiş fakat uç değer tespit edilmemiştir.

Sonuçların $\mathrm{p}<0.05$ olması istatistiksel olarak anlamlı kabul edilmiştir.

\section{BULGULAR}

\section{İstatistiksel veriler}

Araştırma kapsamında yer alan çalışma gruplarından elde edilen verilere ilişkin hem betimleyici istatistikler hem de test istatistikleri, her bağımlı değişken için tek görsel ile sunulmuş ve irdelenmiștir.

Serumda Bakılan Biyokimyasal Parametreler

Oksidatif stresin göstergesi ve lipid peroksidasyonunun bir ürünü olan serum MDA değerinde; travma grubunda, kontrol, dağ nanesi ve zahter gruplarına göre anlamlı artış bulundu ( $p=0,008, \quad p=0,001, p=0,002)$. Travma+dağ nanesi grubundaki MDA artışı ise kontrol ve zahter gruplarına göre istatistiksel olarak anlamlı bulundu ( $\mathrm{p}=0,026, \mathrm{p}=0,048)$. Travma+zahter ile travma+dağ nanesi gruplarında travma grubuna göre istatistiksel olarak anlamlı olmasa da MDA değerinin düştüğü görüldü ( $p>0.05$ ) (Grafik 1).

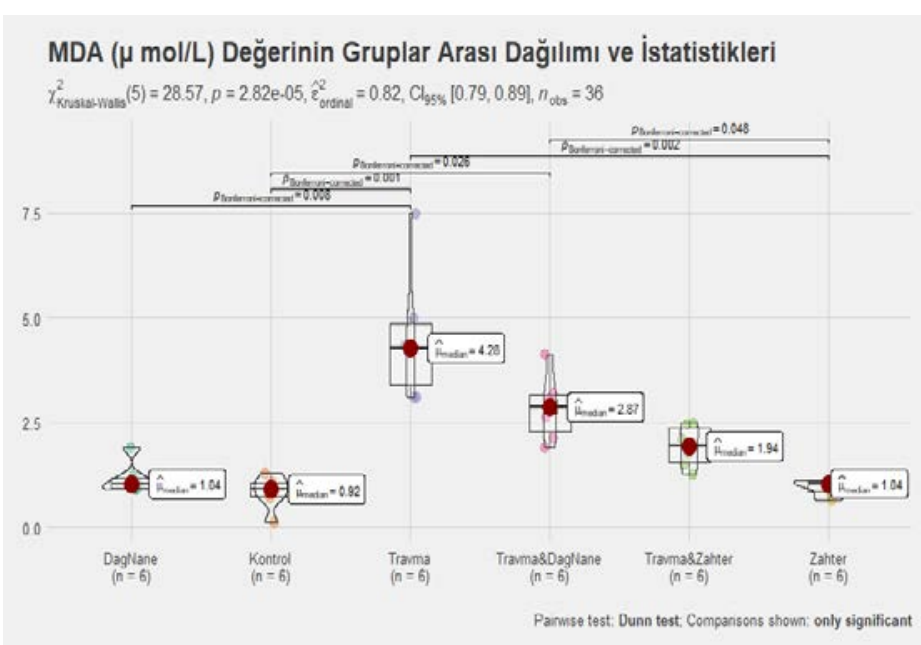

Grafik 1. Grupların serum MDA değerleri

Böbrek fonksiyonlarının göstergesi olan serum kreatinin ve BUN değerleri, travma uygulanan gruplarda, travma uygulanmayan gruplara göre istatistiksel olarak anlamlı farklılık göstermiş ve bu da travmanın gerçekleştiğini göstermektedir.

Serum BUN düzeyindeki artış travma grubunda kontrol, zahter ve dağ nanesi gruplarına göre istatistiksel olarak anlamlı bulundu $(p=0,009$, $\mathrm{p}=0,001, \quad \mathrm{p}=0,004) . \quad$ Travma+zahter ile travma+dağ nanesi gruplarında travma grubuna göre istatistiksel olarak anlamlı olmasa da BUN değerinin düştüğü görüldü $(p>0.05)$ (Grafik 2).

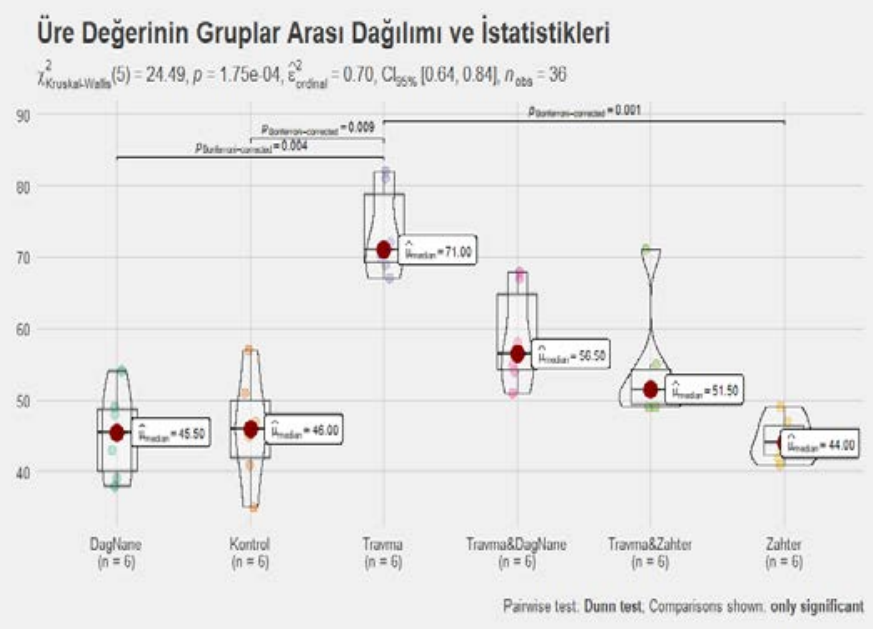

Grafik 2. Grupların serum Üre (BUN) değerleri 
Kreatinin değerindeki düşüş travma+zahter grubunda kontrol ve dağ nanesi gruplarına göre istatistiksel olarak anlaml bulundu $(p=0,044$, $\mathrm{p}=0,037$ ) (Grafik 3).

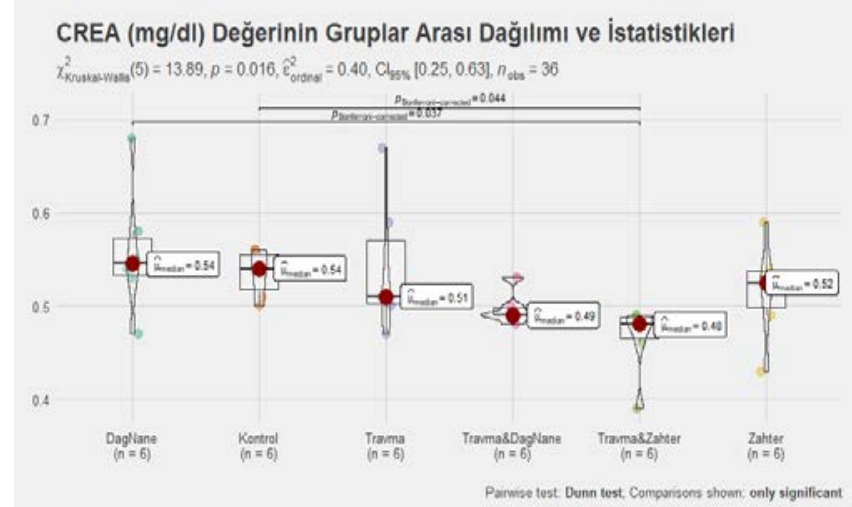

Grafik 3. Grupların serum Kreatinin değerleri

Serum Na değeri travma (Medyan=145,5) grubunda en yüksek seviyede iken, travma+zahter (Medyan=140,5) grubun da en düşük seviyededir. Bu iki grup arasındaki fark istatistiksel olarak anlamlı bulundu $(p=0,005)$. Diğer gruplar arasında Na değeri için anlamlı bir fark görülmedi (Grafik 4).

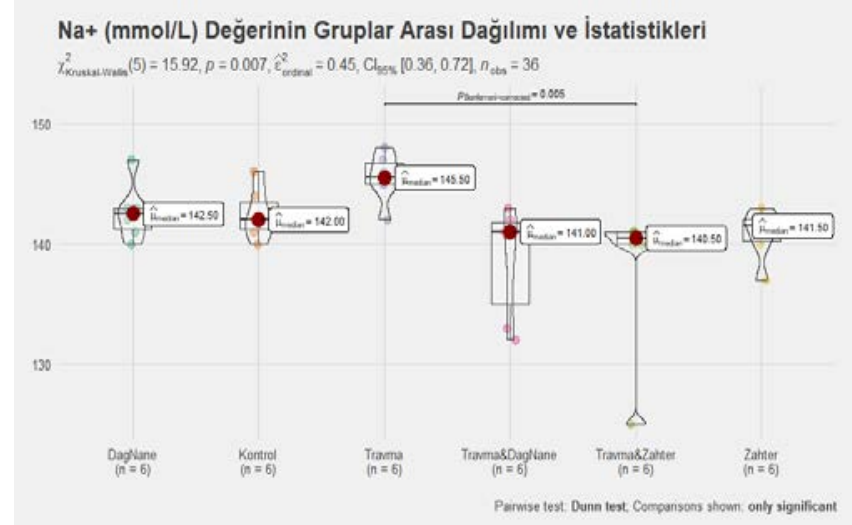

Grafik 4. Grupların serum Na değerleri

Serum K değerinde travma (Medyan=9,66) grubunda kontrol (Medyan=5,17) ve zahter (Medyan=5,84) gruplarına göre istatistiksel olarak anlamlı artış bulundu $(p=0,004$, $\mathrm{p}=0,028)$. Travma+zahter ile travma+dağ nanesi gruplarında travma grubuna göre istatistiksel olarak anlamlı olmasada $\mathrm{K}$ değerinin düştüğü görüldü ( $p>0.05$ ) (Grafik 5).

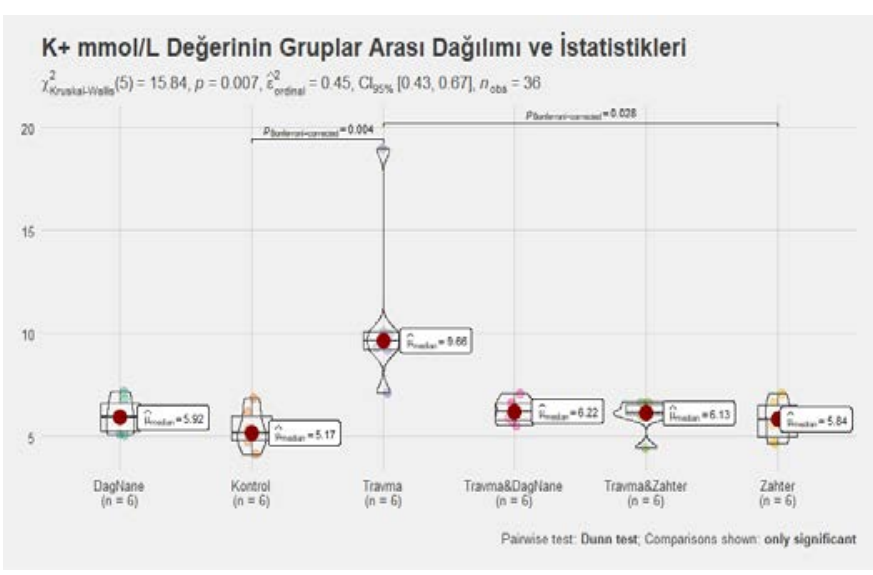

Grafik 5. Grupların serum K değerleri

Histopatolojik incelemede kontrol ve nane grubunda normal böbrek dokusu olduğu görülürken (Şekil 1. A,B), zahter grubunda normal görünümün yanında tubüller arasında damarlarda konjesyon ve dilatasyon (sarı ok) izlendi (Şekil 1. C).

Travma grubunda, glomerüler yapıların küçüldüğü ve atrofiye uğradığı (yeşil ok) ve glomerüler membranlarda kalınlaşma gözlendi. Makula densanın bozulduğu, proksimal ve distal tübüllerin dejenere, proksimal tübüllerdeki fırçamsı kenarın yapısının bozulduğu (siyah ok) ayrıca damarlarda geniş çapta konjesyon ve dilatasyonun yanında hemoraji (kırmızı ok) izlendi. Bazı alanlarda yoğun olarak mononükleer hücre infiltrasyonu izlendi ( sarı ok). Bu grupta normal böbrek dokusunun tüm yapıları ile bozulduğu izlendi (Şekil 1.D). Travma+dağ nanesi grubunda, travma grubuna göre glomerüllerin normale yakın görünümde olduğu (sarı ok) tübül yapısında dejenerasyonun geniş ölçüde azaldığı gözlendi. Tübüller arasında yoğun ve geniş çapta ödem varlığı (siyah ok) ve soliter tarzda mononükleer hücre infiltrasyonu izlendi ( Şekil 1.E). Travma+zahter grubunda, travma grubuna göre glomerüler yapılarda düzelme olduğu (sari ok), proksimal tübüllerin fırçamsı kenarın dejenere olduğu (siyah ok) gözlendi. Tubül dejenerasyonu ve küçük çaptaki damarlarda konjesyon ve dilatasyonun devam ettiği 
(kırmızl ok) yer yer mononükler hücre infiltrasyonun düzeldiği gözlendi (Şekil 1.F).
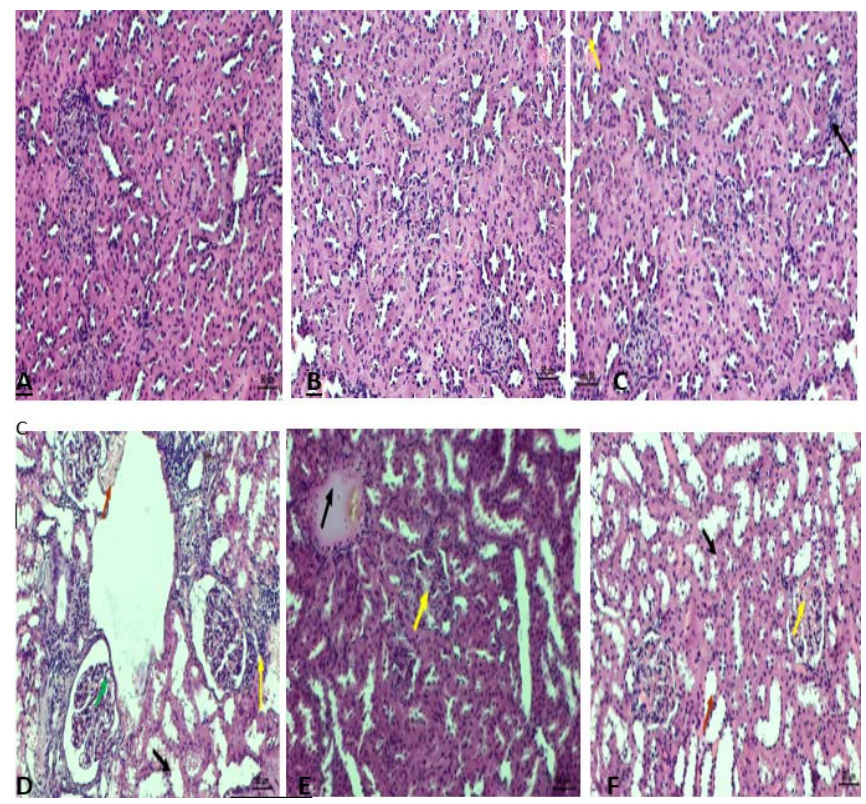

Şekil 1. A) kontrol B) dağ nanesi C) zahter D) travma E) travma+dağ nanesi F) travma+zahter

Hematoksilen - Eozin boyama, Bar: $50 \mu \mathrm{m}$.

\section{TARTIŞMA}

Spinal kord yaralanması sonrası dolaşımdaki nötrofiller aktifleşir ve dokularda nötrofil infiltrasyonuna bağlı olarak ortama salıverilen serbest radikaller oksidatif strese neden olarak doku hasarını hızlandırırlar.

Gris ve arkadaşları yaptığı çalışmada; omurilik yaralanması sonrası böbrek dokusunda nötrofil akışının ilk 2 ile 24 saat arası olduğu 12. Saatte en yüksek düzeye ulaştığı, buna paralel olarak böbrek miyeloperoksidaz aktivitesinin ve lipid peroksidasyon (LPO) düzeyinin arttığını belirlemişlerdir ${ }^{17}$. Lipid peroksidasyon zincir reaksiyonu sonucunda sistemik inflamatuvar yanıt tetiklenerek böbrek hasarını arttırıp daha da şiddetlendirir ${ }^{18}$. Sistemik inflamatuvar cevabın inhibe edilmesiyle hasarın iyileşmesinde katkıda bulunulabilir. Antioksidan maddeler inflamasyonun zararlı etkilerini azaltır veya tamamen ortadan kaldırabilir ${ }^{19}$. Bitki ekstraktlarının antioksidan potansiyelleri, serbest radikal ve oksidatif stresin neden olduğu inflamasyonun yarattığ hastalık riskini azaltmakta ve tedavi de özel bir önem taşımaktadır ${ }^{20}$.

$\mathrm{Bu}$ amaçla antiinflamatuvar, antioksidan antibakteriyel ve nöroprotektif etkisi gösterilmiş olan zahter ve dağ nanesi ekstraktları omurilik yaralanmasına bağlı gelişen renal komplikasyonların önlenmesinde koruyucu rol oynayabilir.

$\mathrm{Bu}$ çalışmada daha önce antiinflamatuvar ve antioksidan etkisi toksisite, kalp hasarı, DNA hasarl, diabetes mellitus, nefropati gibi patolojilerde gösterilmiş olan zahter ve dağ nanesi uygulamasının travmatik omurilik yaralanması sonucu gelişen böbrek hasarı üzerine koruyucu ve tedavi edici etkileri ilk kez araştırıldil ${ }^{21-24}$.

Spinal kord yaralanmalarında doku hasarında iskemi reperfüzyonun büyük bir rolü olduğu ve artan serbest radikallerin lipid peroksidasyonuna neden olduğu bilinmektedir ${ }^{25}$. Lipid peroksidasyon kendi kendini devam ettiren tekrarlanan reaksiyon diziliminde ilerlediğinden oldukça zararlıdır. Lipid peroksidasyonunun ve oksidatif stresin önemli bir göstergesi olan MDA, serbest oksijen radikallerinin membran lipidlerini parçalamasıyla ortaya çıkar ${ }^{26}$. LPO membran akışkanlığını etkiler, membran geçirgenliğini bozar ve membran yapısına kalıcı zararlar verir ${ }^{27}$.

Zeytun ve arkadaşları yaptığı çalışmada; zahterin en güçlü bileşeni olan Carvakrol'ün böbrek reperfüzyon hasarı sonucu böbrek dokusunda ve serumda bakılan MDA değerinin hasara bağlı olarak artığını, Carvakrol verilen tedavi grubunda ise anlamlı olarak düştügünü buna bağlı olarak LPO'u önlediğini belirlemişlerdir ${ }^{28}$.

Çalışmamız travma sonrası MDA seviyesinin travma gruplarında mevcut çalışmalara uygun bir şekilde artığını ve travmanın gerçekleştiğini göstermektedir. Travma+zahter ve travma+dağ nanesi gruplarında travma grubuna göre düşüş gösterse bile tedavi gruplarında ki bu fark 
istatistiksel olarak anlamlı bulunmadı. Bunun deney süresi ve verilen ekstraktların dozuyla ilgili olabileceğini düşünmekteyiz.

Öztürk ve arkadaşları bilateral böbrek iskemi reperfüzyon hasarı üzerine yaptıkları çalışmada, zahterin en güçlü bileşeni olan Carvakrol' ün renal fonksiyonlar üzerine olumlu etkileri olduğunu, iskemiye bağlı olarak kreatinin ve BUN değerlerinin arttığını, tedavi grubunda ise bu biyokimyasal parametrelerin Carvakrol'ün etkisiyle düştüğünü belirlemişlerdir ${ }^{29}$.

Serum kreatinin ve BUN düzeyleri renal fonksiyonların belirleyicilerindendir. Çalışmamızda serum BUN değerinin travma gruplarında yükseldiğini, travma +zahter, travma+dağ nanesi gruplarında travma grubuna göre istatistiksel olarak anlamlı olmasa da dengeleyici yönde azalma olduğunu belirledik. Travma oluşturulan gruplarda BUN değerinin artması, böbrek fonksiyonlarında bir sorun olduğunu göstermektedir.

Serum kreatinin düzeyi açısından, kontrol grubu ile travma+zahter grupları arasında ki farklılık değerlendirildiğinde travma uygulandıktan sonra zahter ekstraktı verilen sıçanların kreatinin düzeyinin kontrol grubuna göre daha düşük olduğu görüldü. Bu sonuca dayanarak, travma uygulandıktan sonra zahter ekstraktı vermenin kontrol grubu değerlerine yaklaştırıp dengelemediğini, değerleri daha da düşüren bir etkiye sahip olduğunu söyleyebiliriz. Bunun sebebini tam açıklayamamakla birlikte spinal kord yaralanmasına bağlı çoklu organ hasarından kaynaklanabileceğini düşünmekteyiz.

Serum K değeri için kontrol ve travma grupları arasında gözlenen istatistiksel farkllılı travma uygulanan sıçanlarda $\mathrm{K}$ değerinin arttırdığını söylemeyi mümkün kılmaktadır. Travma ve zahter grupları arasında fark olmasına rağmen, hem her iki grup için de kontrol grubu arasında fark olmadığından, hem de travma+zahter grubu arasında fark olmadığından anlamlı bir sonuç çıkarmak mümkün değildir.

Serum Na değeri için travma ve travma+zahter grupları arasında fark olmasına rağmen, hem her iki grup için de kontrol grubu arasında fark olmadığından, hem de zahter grubu arasında fark olmadığından anlamlı bir sonuç çıkarmak mümkün değildir. Buna rağmen travma uygulanan siçanlar ile travma uygulandiktan sonra zahter ekstraktı verilen sıçanlar arasında fark olması zahter ekstraktının Na değerini dengeliyor olabilir düşüncesi oluşturmaktadır. Bundan sonra yapılacak çalışmalarda bu konunun derinlemesine irdelenmesi gerektiğini düşünmekteyiz.

Karakaya ve arkadaşları alt ekstremite iskemi reperfüzyonuna bağlı böbrek hasarında histolojik analizler sonucunda glomerüler ve tubüller değişiklik, konjesyon, iltihabi hücre infiltrasyonu tespit etmişlerdir ${ }^{30}$.

Çalışmamızda elde edilen histopatolojik değerlendirme sonuçlarına göre; travma grubunda böbrek dokusunun tüm yapılarıla bozulduğu görülürken inflamasyonun bir belirtisi olan yoğun mononükleer hücre infiltrasyonu görüldü. Travma+zahter grubunda yer yer mononükleer hücre infiltrasyonun düzeldiği, zahter uygulamasının travmanın oluşturduğu patolojik etkileri kısmen düzelttiği izlendi. Zahter uygulamasının alternatif bir metod olarak önerilmesi için farklı doz ve sürelerle yapılacak daha fazla çalışmaya ihtiyaç vardır. Histopatolojik sonuçlarımıza göre nane uygulamasının travmanın oluşturduğu patolojik etkileri iyileştirmede düşük rol oynadığı gözlendi. Travma sonrası oluşan patolojik hasarı önlemek için nane uygulamasının alternatif bir metod olarak önerilmesi için daha fazla çalışma gerekmektedir.

Sonuç olarak zahter ve dağ nanesi ekstraktları spinal kord yaralanması sonucu gelişen böbrek hasarına karşı kısmen etkilidir. Zahterin 
etkinliği hem biyokimyasal hemde histopatolojik bulgularımız sonucunda görülen oksidatif stres ve inflamatuvar belirteçler üzerine dağ nanesine göre daha yüksek düzeydedir.

Antiinflamatuvar ve antioksidan etkinin düşük olması deney süresine bitki ekstraktlarının doz ve uygulama şekline bağlı olabilir. Bu etkenlere bağlı etkilerinin anlaşılabilmesi için daha kapsamlı çalışmalara ihtiyaç duyulmaktadır.

Etik Kurul Kararı: $\mathrm{Bu}$ çalışma, Dicle Üniversitesi Hayvan Deneyleri Etik Kurulu (DÜHADEK) tarafindan 30/05/2019 tarih, 2019/08 protokol numarası ile onaylanmıştır.

Çıkar Çatışması Beyanı: Yazarlar çıkar çatışması olmadığını bildirmişlerdir.

Finansal Destek: Bu çalışma her hangi bir fon tarafından desteklenmemiştir.

Declaration of Conflicting Interests: The authors declare that they have no conflict of interest.

Financial Disclosure: No financial support was received.

\section{KAYNAKLAR}

1. Sun X, Jones ZB, Chen XM, et al. Multiple organ dysfunction and systemic inflammation after spinal cord injury: a complex relationship. J Neuroinflammation. 2016; 13: 260.

2. Bao F, Brown A, Dekaban GA, et al. CD11d integrin blockade reduces the systemic inflammatory response syndrome after spinal cord injury. Exp. Neurol. 2011; 231: 272-83.

3. Bao F, Omana V, Brown A, et al. The systemic inflammatory response after spinal cord Injury in the rat Is decreased by $\alpha 4 \beta 1$ integrin blockade spinal cord Injury team. J Neurotrauma. 2012; 20; 29(8): 1626-37.

4. Yapıcı H. Deneysel olarak oluşturulan spinal kord yaralanmasında trombositden zengin plazmanın etkisinin incelenmesi. Yüksek Lisans Tezi; Marmara Üniversitesi Sağlık Bilimleri Enstitüsü, 2017, İstanbul.
5. Herrera JJ, Haywood-Watson RJ, Grill RJ. Acute and chronicdeficits in the urinary bladder after spinal contusion injury in the adult rat. J Neurotrauma. $2010 ; 27: 423-31$.

6. Akakin D, Kirana D, Ozkana N, et al. Protective effects of melatonin against spinal cord injury induced oxidative damage in rat kidney: A morphological and biochemical study. Acta Histochemica. 2013; 115: 827-34.

7. Tepe B, Sokmen M, Sokmen A, et al. Antimicrobial and antioxidative activity of the essential oil and various extracts of Cyclotrichium origanifolium (Labill.) Manden. \& Scheng. 2005; 335-42.

8. Guzel A, Aksit H, Elmastas M, et al. Bioassayguided isolation and identification of antioxidant flavonoids from Cyclotrichium origanifolium (Labill.) Manden and Schen Pharmacnosy Magazine. 2017; 316-20.

9. Mahmoodi M, Amiri H, Ayoobi F, et al. Carvacrol ameliorates experimental autoimmune encephalomyelitis through modulating pro-and anti-inflammatory cytokines. Life Sci. 2019; 219: 257-63.

10. Bayan Y, Genç N, Kusek M, et al. Determination of chemical compositions antifungal antibacterial and antioxidant activity of Thymbra spicata L. from Turkey. Fresenius Environmental Bulletin. 2017; 26: 7595-9.

11. Gedikoglu A, Sokmen M, Civit A. Evaluation of Thymus vulgaris and Thymbra spicata essential oils and plant extracts for chemical composition, antioxidant and antimicrobial properties. Food Science \& Nutrition. 2019; 7: 1704-14.

12. Doğan S, Turan P, Doğan M, Arslan O, Alkan M. Partial characterization of peroxidase from the leaves of thymbra plant (Thymbra spicata L. var. spicata). Eur Food Res Technol. 2007; 225: 865-71.

13. Allen AR. Surgery of experimental lesion of spinal cord equivalent to crush injury of fracture dislocation of spinal column. A preliminary report. JAMA. 1911; 57: 878-80.

14. Drummond JC, Moore SS. The influence of dextrose administration on neurologic outcome after temporary spinal cord ischemia in the rabbit. Anesthesiology. 1989; 70: 64-7. 
15. Yıldırım MU, Sarıhan EO, Kul H, et al. Diurnal and nocturnal variability of essential oil content and components of Lavandula angustifolia Mill. (Lavender). Mustafa Kemal University Journal of Agricultural Sciences. 2019; 24: 268-78.

16. Ohkawa H, Ohishi N, Yagi K. Assay for lipid peroxides in animal tissues by thiobarbituric acid reaction. Anal Biochem.1979; 95: 351- 8.

17. Gris D, Hamilton EF, Weaver LC. The systemic inflammatory response after spinal cord injury damages lungs and kidneys. Exp Neurol. 2008; 211: 259-70.

18. Aboutaleb $\mathrm{N}$, Jamali $\mathrm{H}$, Abolhasani $\mathrm{M}$, et al. Lavender oil (Lavandula angustifolia) attenuates renal ischemia/reperfusion injury in rats through suppression of inflammation oxidative stress and apoptosis. Biomed Pharmacother. 2019; 110: 9-19.

19. Kolaç T, Gürbüz P, Yetiş G. Doğal ürünlerin fenolik içeriği ve antioksidan Özellikleri. İnönü Üniversitesi Sağlık Hizmetleri MYO Dergisi. 2017; 5: 1-17.

20. Sowndhararajan K, Joseph JM, Manian S. Antioxidant and free radical scavenging activities of indian acacias: Acacia leucophloea (roxb.) wall açacak feriğine Dc. acacia dealbata link. and acacia pennata (L.) wall. International Journal of Food Properties. 2013; 16: 1717 -29.

21. Çektik S. Sıçanlarda siklofosfamid nedenli kardiyotoksisitede oksidatif stres ve kalp hasarına karşı karvakrol' ün koruyucu etkisi. Osman Gazi Üniversitesi Sağlık Bilimleri Enstitüsü, Doktora tezi, 2014.

22. Dikilidal M, Ozdemir H, Oto G, Yilmaz A. Effects of thymus vulgaris L. and thymbra spicata L. on diabetes mellitus associated cognitive impairment and neuropathy: Thymus Vulgaris and Cognitive Function Improvements Medical Science and Discovery. 2014; 1:16-21.
23. Joma MH, Çay M, Kılıç İH, Özaslan M. Zahter (Thymbra spicata L. var. spicata) bitki özütlerinin DNA koruyucu aktivitelerinin ve stenotrophomonas maltophilia üzerine antimikrobiyal etkisinin araştırılması. Zeugma Bıological Scıence. 2020; 1: 28-34.

24. Uzun K: Etil alkol ve karbon tetraklorüre maruz kalan sıçanlara cyclotrichium niveum ekstraktının bazı biyokimyasal parametreler üzerine etkisi. Doktora Tezi. Adıyaman üniversitesi, 2014.

25. Sun Y, Liu D, Wang Q, et al. Hyperbaric oxygen treatment of spinal cord injury in rat model. BMC Neurol. 2017; 17: 128.

26. Aslan A, Cemek M, Buyukokuroglu, et al. Dantrolene can reduce secondary damage after spinal cord injury. Eur. Spine J. 2009; 18: 1442-1451.

27. Ates M, Köksal MH, Celayir MF, et al. Prophylactic and therapeutic effect of ginko biloba extract (Egb761) on mortality of intestinal deep ischemia reperfusion model in rats. Dicle Med J. 2010; 37: 199-203.

28. Zeytun H, Basuguy $\mathrm{E}$, İbiloğlu İ, ve ark. Carvacrol'un ratlarda böbrek iskemi reperfüzyon hasarı üzerine koruyucu etkileri. Dicle Tıp Dergisi. 2020; 47: 696-703.

29. Ozturk H, Cetinkaya A, Duzcu SE, et al. Carvacrol attenuates histopathogic and functional impairments induced by bilateral renal ischemia/reperfusion in rats. Biomed Pharmacother. 2018; 98: 656-61.

30. Karakaya A, Babaroğlu S, Yllmaz F, ve ark. Akut alt ekstremite iskemi reperfüzyon sonrasında gelişen böbrek hasarına iloprost ve levosimendanın etkilerinin araştırılması. Damar Cer Derg. 2014; 23 : 34-9. 